\title{
Smart City Comprehension in Community Development
}

\author{
$\mathrm{Riki}^{1}$, Setyawan Widyarto ${ }^{2}$, Saliyah $\mathrm{Kahar}^{3}$, Susanto Hariyanto ${ }^{4}$ \\ \{1 riki@ubd.ac.id, ${ }^{2}$ swidyarto@unisel.edu.my, ${ }^{3}$ saliyah@unisel.edu.my\} \\ Universitas Buddhi Dharma, Jl. Imam Bonjol No. 41, Karawaci Ilir-Tangerang, Indonesia, ${ }^{1,4}$ \\ Universiti Selangor, Jalan Timur Tambahan, 45600 Bestari Jaya, Selangor Darul Ehsan, Malaysia ${ }^{2,3}$
}

\begin{abstract}
Smart growth, digital city, intelligent city, and successful city, have become more common in several countries and in the literature. To understand these concepts it is very important to consider that cities are a key element for the future because cities have a big impact on social, economic and environmental aspects. Improved smart city services and mutually connected (integrated) and efficient services in administration, education, health, security, settlement, transportation and other public utilities. The method used in the indicator follows Boyd Cohen Smart City Wheel (an indicator to measure the progress of a smart city) Develop smart cities that prioritize the interests of citizens where they need the right indicators, an integrated database and inter-sector cooperation that includes several key factors. Factors to be discussed: smart transportation, smart economy, smart environment, smart (educated) people, smart living, smart governance. So that it is expected that by discussing indicators of smart cities can produce smart society..
\end{abstract}

Keywords: SmartCity BCSCW, Community, Development.

\section{Introduction}

In the past two and a half decades, words like, "smart city", "smart growth", "digital city", "intelligent city", and "successful city", have become more common in several countries and in the literature. To understand these concepts it is very important to consider the city as a key element for the future because the city has a big impact on social, economic and environmental aspects [1]. Some approaches have developed a turn on technology to help create what is now called a smart city. The concept of a smart city is not limited to one answer, one idea, or one city technology application; different groups for various people. Definition from city to city, and country to country related to development. Smart city as "the use of smart technology to create urban infrastructure and services that include city administration, education, community, health, and smarter, interconnected and efficient utilities. Investigate the ability of the system to improve livability, workability and the sustainability of cities [2]. Brand smart cities as "cities that invest in people and social capital, development and information technology and modern infrastructure (ICT); provide sustainable economic growth and high quality standards, and regulate natural resources with governance. The criteria of a smart city is a city that provides six factors: intelligent transportation, smart economy, smart environment, smart people (educated), intelligent life, and smart governance [3]. The smart city is a city that monitors and includes all critical infrastructure conditions, 
including roads, bridges, tunnels, trains / subways, airports, ports, communications, air, electricity, even the main buildings that can be better than daytime, plan preventive maintenance activities, and include aspects that cause death. Calculating that the city's livability, workability and sustainability can advance infrastructure compilation is developed. For example, the feasibility of life provides a better quality of life for people [4]. The Brundtland Commission's report has determined that citizens must have more access to a green, clean, safe, comfortable and healthy lifestyle, while employability means developing an economy with better work and sustainability using resources to reach the present without the ability of the Times the future to meet their own needs [5]. Therefore, smart city factors can be broken down into six categories: transportation, economy, environment, people, life and government) [6] (see Fig. 1)

\section{Literature Review}

\section{a. Smart Transportation}

Movement of people or goods around the city, from one location to another and around the world. In other words, "transportation is really a simple idea. We want to move ourselves or our goods from one place to another efficiently, reliably and safely" [7], for example: going to the office, attending college, and Other activities in the city depend on transportation routes and modes of transportation such as trains, motorbikes, buses, bicycles, cars, and others.

b. Smart Economy

The interface between smart and economic city. Smart economy goal:

1) Improve business life,

2) Facilitate and produce faster business services,

3) Participate in urban development,

4) Increase gross domestic product, and

5) Creating employment

c. Smart Environment

The smart city environment is designed to improve sustainability, clean energy, clean air and clean water. By reducing air pollution, water pollution and $\mathrm{CO} 2$ emissions, environmental conditions can help develop smart cities. The sustainability of the development and management of these resources depends on technology as the core concept of a smart city.

d. Smart (educated) People

People with diversity, education and creativity are important for the growth of smart cities because people are generators for other factors. Smart People can create a smart economy, smart education, and smart transportation. Many indicators can measure smart people like; education level, academic and professional degree, additional training, and the ability to communicate in more than one language [8].

e. Smart Living

One of the goals of a smart city is to improve the quality of life. Therefore, smart living is defined by providing a better life for citizens through health care, security, housing quality, social mix and other activities in society [9]. 


\section{f. Smart Governance}

Smart governance means that various stakeholders are involved in decision making and public services. Government-mediated information and communication (ICT) technology, also referred to as e-governance, is very important in bringing smart city initiatives, citizens to maintain decisions and transparent implementation processes. However, the spirit of e-governance in a smart city must be citizen-centered and driven by citizens.

\section{Methods}

To achieve the object proposed from this research, the following steps can be taken:

a. Review of the literature on smart city concepts, including: journals, reports, research related to smart cities

b. Collect data on 3 major cities in Indonesia to be evaluated, measured and compared

c. Analysis of data grouped according to appropriate categories

d. Results using indicators found in Boyd Cohen Smart City Wheel.

e.

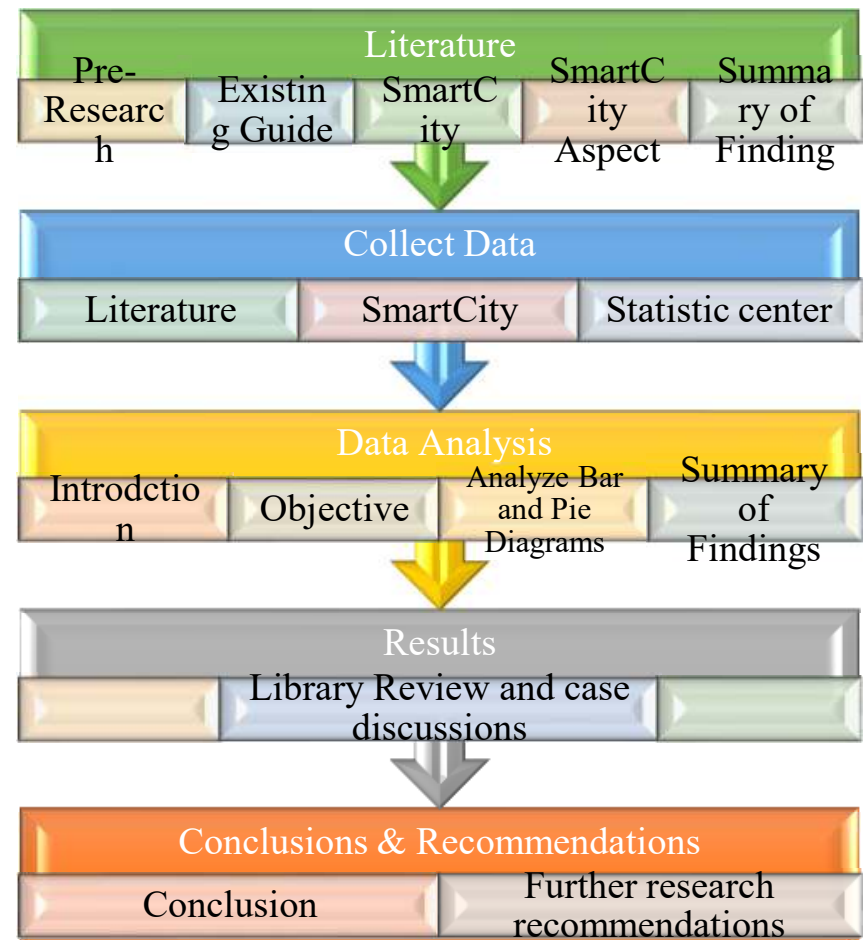

Fig. 2. Framework 


\section{Results}

Object of this research to obtain and express:

a. Smart and connected and efficient urban services, urban service integration such as administration, education, health, security, housing, transportation and utilities

b. Sustainable economy and quality of life and city with future performance, from six smart city factors and strong ICT services

c. Continuous integration and monitoring, natural resource optimization, management, security and maximum service to the community.

d. Urban intelligence collectivity, connecting infrastructure (physical, social and business) and ICT

e. Sustainable economic development and quality of life, SDA management is a participatory government

f. What measurement is used as an indicator that can be used by cities in Indonesia

g. City ranking of each indicator

h. Use and integrate data from each department or institution to produce indicators that are made

i. Assisting citizens to the indicators given in terms of the potential of their respective regions or

j. regions in accordance with local wisdom

k. There is still a contradiction between theories and the situation in the field in terms of the application of smart cities

1. To find solutions to problems caused by increasing urbanization, cities struggling to manage extraordinary population growth and their influence on the city's population.

m. Cities face many problems in health care, education, safety, transportation and the environment.

n. Implementation of the smart city concept and its relationship with community participation

o. The services provided by the Government for public services are still far from comfortable and not transparent

p. Congestion is a problem that is felt every day by the community

q. Community security, given the higher crime rate

\section{Discussion}

Increasing population from year to year and limited natural resources make city management more complex. This condition requires the Regional Government to be able to maximize the potential of its resources and minimize the obstacles or problems faced. The concept of a smart city which is a big issue in big cities around the world encourages active role and community participation in city management using a citizen centric approach so that there is a more dynamic and close interaction between citizens and service providers, in this case the City Government. This two-way interaction will continue to evolve and process so that in the future the city will become a comfortable place to live and be resilient in responding to new changes and challenges more quickly.

With increasing population, the economy will also grow, this growth will affect the city in various ways. Cities will inevitably face internal problems; health care, education, safety, 
transportation and the environment. With this it is increasingly important for cities to come up with smart solutions to improve sustainability, livability and workability.

a. Population and Resources

Interaction between people has moved towards a socio-technical ecosystem where the physical and virtual dimensions of the lives of urban citizens are increasingly intensively intertwined. Interaction between citizens is intertwined with stronger and more impermeable technology mediation.

Attention is paid to the environment in urban development which is as large as the attention given to the development of physical infrastructure and the development of facilities and infrastructure for citizens.

1) Realizing Efficient Community Interaction

2) Building Efficient Learning Ecosystems

3) Realizing the Community Security System

4) Harmonization of Regional Spatial Planning

5) Realizing Health Infrastructure

6) Ensuring Availability of Transportation Facilities

7) Develop an Environmental Protection Program

8) Developing Waste and Waste Management

9) Develop Responsible Energy Governance

b. Government and Services

Overview of governance that is carried out intelligently, namely governance that is able to change traditional patterns in the bureaucracy so as to produce a business process that is faster, effective, efficient, communicative and always makes improvements. Innovation in marketing the region so that it can improve regional competitiveness by developing three elements, namely tourism, business, and the face of the city, because in the information age like today, a city no longer has to be able to meet its needs by only utilizing its local potential, but must also be able to attract the participation of the community, both from within and outside the region, as well as business people and investors to contribute to the acceleration of regional development.

1) Public Services

2) Efficient Management of Bureaucracy

3) Public Policy Efficiency

4) Building and Marketing Tourism Ecosystems

5) Building platforms and marketing regional business ecosystems

6) City Appearance Branding

7) Building competitive industrial ecosystems

8) Realizing the People's Welfare

9) Building a Financial Transaction Ecosystem.

\section{Conclusion}

As mentioned earlier, the population and economy are expected to increase in the coming decades. This growth will affect cities in various ways. Applying the concept of a smart city will help solve some of the problems facing the city. The questions you want to discuss are:

a. Smart city influences city growth

b. Indicators of smart city development, and 
c. Compare smart cities with smart city indicators

d. Construction of application e-governance

e. Lay the data base to connect and integrate various departments and institutions

This study describes the components of the smart city and the various problems faced by the city.

\section{References}

[1] K. Mori a A. Christodoulou, „Review of Sustainability Indices and Indicators: Towards a New City Sustainability Index (CSI). Environmental Impact Assessment Review,“ Elsevier, zv. 32, \%1. vyd.1, pp. 94-106, 2012.

[2] D. Washburn, U. Sindhu, S. Balaouras, R. A. Dines, N. M. Hayes a L. E. Nelson, Helping CIOs Understand -Smart City Initiatives: Defining the Smart, MA: Cambridge, 2010.

[3] A. Caragliu , C. F. D. Bo a P. Nijkamp , „Smart cities in Europe,“ Journal of Urban Technology, pp. 65-82, 2011.

[4] R. E. Hall, B. Bowerman, J. Braverman, J. Taylor, H. Todosow a U. V. Wimmersperg, „The Vision of a Smart City," rev. Proceedings of the 2nd International Life, Paris, 2000.

[5] G. H. Brundtland, Report World Commission on Environment and Development. 1987. Our Common Future, Oxford: Oxford University Press, 1987.

[6] F. Purnomo, M. a H. Prabowo , „Smart City Indicators: A Systematic,“ Journal of Telecommunication, Electronic and Computer Engineering, zv. 3, \%1. vyd.3, pp. 161-164, 2016.

[7] A. Foxx

„https://www.transportation.gov/sites/dot.gov/files/docs/Draft_Beyond_Traffic_Framework.pdf,“

U.S. Departement of Transportation, 28 Februari 2015. [Önline]. Available: https://www.transportation.gov/sites/dot.gov/files/docs/Draft_Beyond_Traffic_Framework.pdf.

[8] T. Nam a T. A. Pardo, Smart City as Urban Innovation: Focusing on Management, Policy, and Context, US: Center for Technology in Government, 2011.

[9] L. Batagan, „Indicators for Economic and Social Development of Future Smart City,“ Journal of Applied Quantitative Methods, zv. 6, \%1. vyd.3, pp. 27-33, 2011. 